\title{
Pakistan's Foreign Policy Towards Central Asia in Context with CPEC
}

\author{
Aamir Junaid \\ M.Phil, International Relations \\ Department of Political Science and International Relations \\ Government College University \\ Faisalabad-Pakistan \\ aamirjunaid798@gmail.com \\ Dr. Ghulam Mustafa \\ Assistant Professor \\ Department of Political Science and International Relations \\ Government College University \\ Faisalabad-Pakistan \\ ghulammustafa@gcuf.edu.pk \\ Muhammad Ashraf Nadeem \\ M.Phil.International Relations \\ Department of Political Science and International Relations \\ Government College University \\ Faisalabad-Pakistan \\ ashrafnadeembaloch@gmail.com
}

\begin{abstract}
Central Asia consists of five states: Tajikistan, Uzbekistan, Turkmenistan, Kazakhstan, Kyrgyzstan, and rich with natural reserves. Pakistan has an important place in the South Asian region and occupies an important strategic location. Pakistan and Central Asian republics always keen to develop cordial relations. China Pakistan Economic Corridor (CEPC) is a game-changer project of the region. China has injected over $70 \$$ billion under CPEC in various projects in Pakistan and wants to invest more. Central Asian states are willing to join CPEC and wish to get benefits from this vital project. Central Asian republics can capture a large-scale market beyond South Asia and Pakistan, with its prime location can provide an accessible route. Gawadar Port is fully functional now and provides a transit route to the Central Asian republics and can significantly enhance ties among Pakistan and CARs. Now Pakistan
\end{abstract}




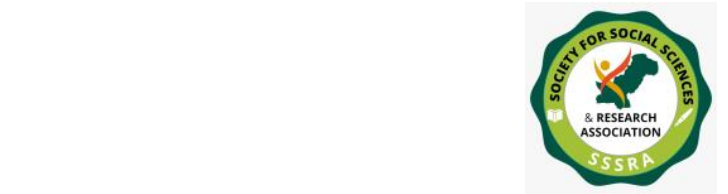

Pak. Journal of Int'L Affairs, Vol 4, Issue 2 (2021)

Pakistan's Foreign Policy Towards ...

considers the Central Asian region an essential pillar in its foreign policy. Islamabad tried its best to connect with the Central Asian region but could not get the desired results due to the various regional issues. Afghanistan is a constant hurdle in the way of a prosperous region. Afghanistan has been in war for the last four decades, and peace looks like a dream in the country. Islamabad has hosted Tajik President in June and the Uzbek President at the virtual meeting in April this year. Pakistan has signed various MoUs with both Central Asian states and it shows the importance of relations among Pakistan Central Asian republics. This paper analyzes Pakistan's foreign policy towards Central Asia in the context of CPEC. The researcher uses a qualitative technique to complete his research paper and this research paper enables readers to understand the significance of CPEC and Pakistan's relations with Central Asian states.

Keywords: Pakistan, China, Central Asia, CPEC, Geo-Strategic, South Asia

\section{Introduction}

Since the independence of Pakistan, Islamabad has been trying to enhance its ties with the Central Asian states rich with natural resources. Pakistan and the Central Asian region have historical, cultural, religious and economic linkages. Modern-day Pakistan had been a gateway to the Central Asian region for centuries. Pakistan and Central Asia enjoy historical ties and both parts have an element of respect for each other. The silk route was the old route; most of the people used it for trade. The Silk route boosted the economic activities between the South and Central Asian region. Afghanistan also had great importance, while Peshawar was the trading hub and Hindko has used trade dealings (Sofi, 2019). The emergence of Central Asian states after the disintegration of the USSR in 1991attracted the state of Pakistan to develop cordial ties with CARs. Afghanistan was the hurdle between Pakistan and Central Asian states. Taliban took control in 1996 and remained in government till 2001. Pakistan's relations with CARs remained uneasy during the regime of the Taliban. After the demise of the Taliban regime, Pakistan approached diplomatically to the CARs and tried to enhance ties. The Central Asian region, without any doubt, is rich in natural resources. World powers are very keen to explore the Central Asian region to fulfill their energy demands. Pakistan always remained eager to establish cordial ties with Central Asian states to meet its energy deficit (Dawn, 2020). The Central Asian region has immense oil and gas reserves abundance in minerals and agriculture activities with skilled labor it can become a dynamic region on the world map. China Pakistan Economic Corridor provides a chance to the CARs to expand their wings to the outer world. Pakistan is also considering CPEC 


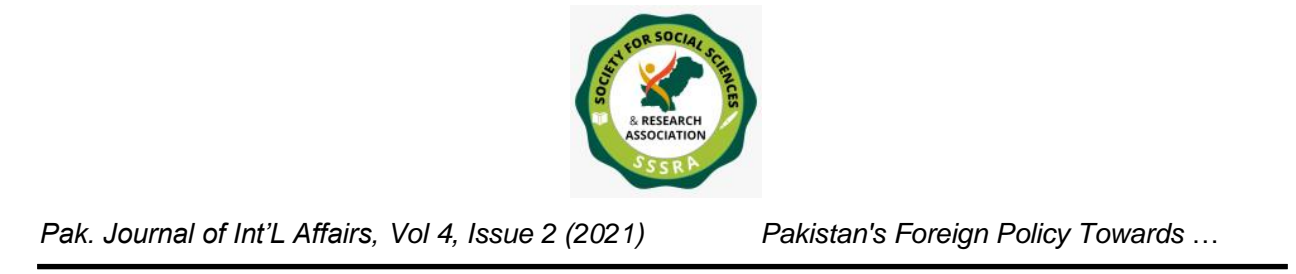

a golden opportunity to enhance its ties with the CARs by providing them with the sea route. China has injected over $\$ 64$ billion under the CPEC (Hassan, 2020). Afghanistan is the key player in this region and has been in the war for almost four decades. Peace in Afghanistan is compulsory to enhance trade ties with Central Asian states. Pakistan is playing its constructive role in bringing durable peace to Afghanistan. America signed a peace deal with the Taliban on February 29, 2020, in the capital city of Qatar (Mustafa, Yaseen, \& Junaid, 2020). Pakistan is taking a great interest in the Afghan peace process and keeping an eye on enhancing trade ties and diplomatic relations with CARs. This paper highlights Pakistan's foreign relations with Central Asian states and the importance of CPEC in the context of Central Asian states.

\section{Research Methodology}

Central Asian states have a significant place on the world map due to their natural wealth. This paper has tremendous importance due to the changing world political structure. The writer applied the qualitative method to complete his research paper. The writer finds it helpful to study existing literature to complete his research work. He also discussed his topic with scholars to get beneficial information and met different personalities to obtain relevant data.

Media sources were used to obtain accurate data to complete research work. This research was based on secondary data and the writer had visited various institutions and libraries. Newspapers, journals and online material was searched to complete this research paper.

\section{Literature Review}

Prospects of Pakistan-Central Asia Economic Relations by Umbreen Javaid and Naheeda Naseem explain the importance of CARs and their relations with South Asian states, especially Pakistan. Central Asian states are rich natural resources but economically weak. The geographic location of CARs is the biggest hurdle in the way of progress. Central Asian states have no access to the sea and it is the most significant to get access to the outer world. Pakistan enjoys a long coastal line, and Central Asian states can benefit from Pakistan's ports, especially Gawadar. Central Asia and South Asia can increase their trade volume by joining hands and it is the best way to overcome poverty in both regions (Javaid \& Naseem, 2014).

Pakistan's Interests/Opportunities \& Constraints in Central Asian States, Naheeda Khatoon and Isma Younes describe the challenges and opportunities for Pakistan in the 


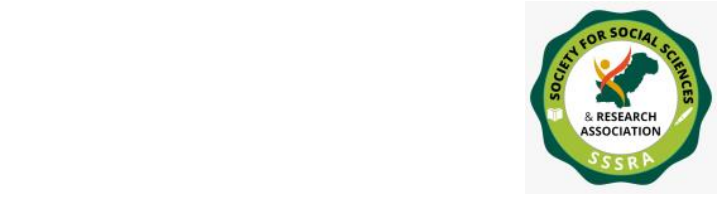

Pak. Journal of Int'L Affairs, Vol 4, Issue 2 (2021)

Pakistan's Foreign Policy Towards ...

Central Asian region. Russia always took great interest in getting access to warm waters, but British authorities considered it a threat to their colonial system and prevented Russia from gaining access to the Arabian Sea; it was called "the Great Game." Pakistan enjoys a long coastal line, whereas the Central Asian states have no direct access to the sea. Central Asian republics are isolated from the whole world due to their geographical location and called the backyard of Russia. Pakistan has historical-cultural, religious and economic ties with the Central Asian region. The disintegration of the USSR provides a chance for CARs to reach out to the outer world. The writers highlight the challenges Pakistan is facing to enhance its trade volume with CARs and, at the same time, show the way towards prosperity (Khatoon \& Younes, 2019).

Strategic and Economic Interests of Pakistan and India in Central Asia by Mubeen Adnan and Bushra Fatima highlight the importance of Central Asian states for Pakistan and India. The Central Asian region shares historical, cultural and religious affiliations with South Asia, especially Pakistan and India. Pakistan and India both want to explore the untapped natural reserves in Central Asia. Islamabad shares a long border with Afghanistan and hopeful of bringing durable peace to the neighboring country. Pakistan wants to enhance its trade volume with the CARs. On the other hand, India is also increasing its influence in Afghanistan and investing a handsome amount in getting closer to the Central Asian states. Afghanistan has been in the war for the last four decades and it is the biggest hurdle in the way of prosperity (Adnan \& Fatima, 2015).

China Central Asia Relations and Opportunities for Pakistan by Umbreen Javaid and Azhar Rashid describe China's ties with the Central Asian states and prospects for Pakistan. China is the world's best economy right now and regional states like Russia, Japan, Korea and India, and world power America considering Beijing a threat. China is situated in the East Asian region and shares borders with 14 countries, including 3 Central Asian countries Tajikistan, Kazakhstan and Kyrgyzstan. The Central Asian region has great importance due to the abundance of natural resources. China is very keen to explore the Central Asian area to fulfill its energy demands. China Pakistan Economic Corridor is the flagship project of the Chinese One Belt One Road initiative. China is investing in energy, agriculture, information technology and infrastructure projects under CPEC. Central Asian republics can get benefits from CPEC to get access to the outer world. Pakistan can boost its trade volume with CARs through CPEC, Gawadar port can play a significant role in this regard (Javaid \& Rashid, 2016).

The Analysis of Regional Bilateral Trade Between Pakistan and Central Asian Republics by Saleem Khan, Sher Ali and Saima Urooge highlight the trade potential between Pakistan and Central Asia. Pakistan has great importance due to its strategic location. 


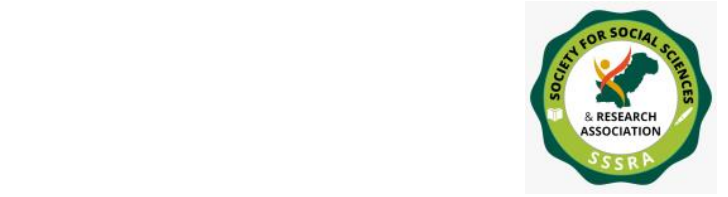

Pak. Journal of Int'L Affairs, Vol 4, Issue 2 (2021)

Pakistan's Foreign Policy Towards ...

Central Asian republics are rich in natural wealth but do not have direct access to the sea. Sea route plays a vital role to enhance the trade volume of a country. Central Asian states want to get in touch with Pakistan due to its coastal line. Although CARs have abundant natural reserves, it is difficult for them to reach out to the outer world due to their geography. Pakistan can play a vital role in increasing the trade volume of CARs. Islamabad also can fulfill its demands of energy (Khan, Ali, \& Urooge, 2019).

The China- Pakistan Economic Corridor Gateway to Central Asia by Mir Sher Baz Khetran and Muhammad Humayun explain the importance of the China Pakistan Economic Corridor for the Central Asian states. CPEC is the flagship project of China's One Belt One Road program. It was started in 2015 and China has invested over \$62 billion in CPEC and it is a landmark project in the Paki-China relations history. China Pakistan Economic Corridor benefits China and Pakistan and all the regional players, particularly Central Asian republics. Gawadar port is functional now and CARs can increase their trade volume by using Gawadar port. Central Asian states are landlocked and rich with natural resources and Gawadar port provides the shortest sea route to CARs. Pakistan and China want to explore Central Asia to meet their energy needs. CPEC offers a strategic opportunity for CARs to sell their products in the global market (Khetran \& Humayun, 2019).

Central Asia has historical, cultural and religious ties with Pakistan. World politics is changing day by day due to the tussle between America and China. Different authors have worked on Central Asian states' relations with South Asian countries. There is a need to work on Pakistan's foreign policy towards Central Asia. This paper focuses on Pakistan's foreign policy towards CARs and the importance of CPEC.

\section{Research Questions}

1. What is the foreign policy of Pakistan towards Central Asian states

2. What is the importance of CPEC for Central Asia

\section{Foreign Policy of Pakistan towards Central Asia and CPEC}

After the disintegration of the USSR, the Central Asian states are critical due to their energy potential. Central Asian states cover a significant portion of the world and have strategic closeness with South Asia; CARs have massively political and economic significance. CARs consists of five states of the former USSR: Kazakhstan, Kyrgyzstan, Tajikistan, Turkmenistan, and Uzbekistan. All states have no direct access to the sea and rich in natural resources. Islamabad and Central Asian republics share different religious 


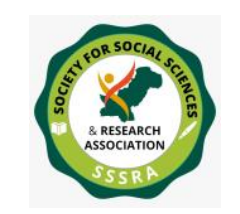

Pakistan's Foreign Policy Towards ...

and cultural similarities. However, Pakistan had not established close relations so far. However, Islamabad wishes close political and economic links with the CARs (Bhatti, 2017). CARs always have an important place in Asian \& world political history. Pakistan and Central Asian states' relationship can be of mammoth consequence because both sides can benefit from the blessed natural and geographic potential to boost their social and cultural cooperation. As far as Central Asian benefits are concerned, Pakistan's geostrategic location is of excessive significance. It provides the weightiest influential, cost-effective, and short opening access for its energy reserves to the real outer world through Port Qasim and Gwadar. Moreover, the capitals of CARs can use these ports to enhance their trade with the outside world through cost-effective routes to boost economic activity in the region. As for Pakistan, the importance of Central Asia cannot be neglected in any way. Pakistan turned out to be a key energy export track in the entire operating situation would uplift its international status and would be able to solve its economic and social problems. Furthermore, it will manifest more profound interest of the international community in its stability and security; however, to benefit from the CARs resource potential, Afghanistan's stable government is a must and in the broader interest of Pakistan (Khatoon \& Younes, 2019). Afghanistan is suffering from war for the last four decades. Pakistan always worked hard to bring stability and peace to Afghanistan. There are two crucial things Islamabad does not want in Afghanistan.

The first is a hasty American withdrawal. If America does so, Pakistan thinks the civil war will erupt once again and kill each other. Pakistan also does not want a government against Islamabad's interests in Kabul. Islamabad does not wish for a more friendly government with India than with Pakistan. And it is no secret that it has had a turbulent relationship with the Afghan government (Afzal, 2020). Peace in Afghanistan is necessary to enhance trade activities in the region. CARs importance depends upon its geographic location and substantial natural resources. Since independence, Pakistan has tried to establish strategic relations with the Central Asian states. China Pakistan Economic Corridor (CPEC) is One Belt One Road (OBOR). CPEC is a game-changer project not only for Pakistan but all regional players. China has invested over $\$ 64$ billion in Pakistan under CPEC (James, 2021). CPEC is a vital opportunity for the Central Asian states to reach out to the outer world. Pakistan enhances trade and defense links with Central Asian states. Tajikistan's President visited Pakistan and signed various agreements on trade and defense. The two states have signed multiple agreements and Memorandums of understanding to increase cooperation in business, economy, energy, education, art, culture and strategic partnership. An MoU was signed to eradicate corruption and cooperate and learn from each other's experiences in dealing with financial crimes. An Academic Cooperation Agreement was also inked between Tajik Technical University and the Indus University of Pakistan. Various agreements on 


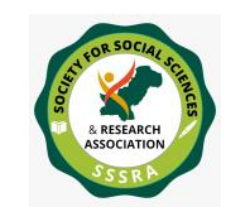

Pakistan's Foreign Policy Towards ...

cooperation between the Chambers of Commerce and Industry of Tajikistan and Pakistan were also inked (Latif, 2021). Pakistan wants to connect Central Asian states with CPEC, Uzbekistan and Pakistan have signed a rail agreement. In Tashkent on February 2, Pakistan, Uzbekistan, and Afghanistan agreed to build a 573-kilometer route from Mazare-Sharif to Peshawar via Kabul. At an estimated cost of \$5 billion, this project will open Pakistani seaports on the Arabian Gulf to Uzbekistan and continue Afghanistan's gradual integration into the Central Asian economic system (Ollard, 2021). Turkmenistan, Afghanistan, Pakistan and India (TAPI) gas pipeline projects will overcome the gas shortage problems in Pakistan. TAPI projects have been delayed due to various reasons. TAPI has two phases: the first one is the free flow phase with an estimated cost of $\$ 5$ billion to $\$ 6$ billion. The second one is to install a compressor of $\$ 1.9$ billion to $\$ 2$ billion (Bhutta, 2019).

Pakistan's strategic position provides Central Asian states with a unique opportunity to expand their wings to the outer world. CARs have the potential to provide gas and oil and other natural reserves to Pakistan and the world. Pakistan wishes peace and stability in the region and trying hard to bring all segments of Afghan society on one page. The rail project and TAPI project cannot be completed without durable peace in Afghanistan. American hasty withdrawal will create a power vacuum in Afghanistan; maturity from Afghan leadership can save Afghanistan from another civil war (The Afghanistan Times, 2021). Pakistan and Central Asian states eager to cooperate and get benefits from each other's experiences. The economy is the biggest issue in Pakistan; CPEC is a project that can change the country's economic situation. Islamabad is trying to enter more and more countries to invest in CPEC projects to boost the country's economy. Central Asian states are willing to join CPEC to increase their trade volume with Pakistan and the outer world. CARs and Pakistan both can enhance cooperation in various fields to stabilize the economies of the countries.

\section{Conclusion}

Central Asia is a prosperous region with natural reserves and it is landlocked, whereas Pakistan has a significant geostrategic position in the area. Pakistan provides suitable routes to the Central Asian states to engage with the outer world. China Pakistan Economic Corridor will boost the opportunities for the Central Asian republics to export their energy items to the world. Gawadar Port is a gateway to the Indian Ocean and no one can deny the importance of the Indian Ocean. Central Asian states are using Gawadar port as a transit route. Pakistan is also willing to promote its defense industry as well. Pakistan has signed various agreements on defense with the Central Asian republics. Central Asian states and Pakistan can increase cooperation in agriculture, energy, 
information technology and security. Peace and stability in Afghanistan are compulsory to enhance trade volume in the region; militant activities in Afghanistan have a spillover effect on the whole Central Asian area. Major powers and global powers are taking an interest in CARs due to the abundance of natural wealth. Pakistan should shape its foreign policy to keeping in mind the changing trends of the $21^{\text {st }}$ century. The trade war between America and China affects the whole world and Pakistan should carefully adopt its balanced policy. Cooperation between Pakistan and the Central Asian region can change the economic fate of the area. 
Pakistan's Foreign Policy Towards ...

\section{References}

Adnan, M., \& Fatima, B. (2015). Strategic and Economic Interest of Pakistan and India in Central Asia. South Asian Studies, 30(2), 187-200.

Afzal, M. (2020, June 25). Will the Afghan peace process be Pakistan's road to redemption? Retrieved June 30, 2021, from Brookings: https://www.brookings.edu/blog/order-from-chaos/2020/06/25/will-the-afghanpeace-process-be-pakistans-road-to-redemption/

Bhatti, B. A. (2017, November 27). Pakistan and Central Asian Republics. Retrieved June 30, 2021, from Russian International Affairs Council: https://russiancouncil.ru/en/blogs/baber-ali-bhatti/pakistan-and-central-asianrepublics/

Bhutta, Z. (2019, March 13). TAPI gas pipeline makes headway. Retrieved July 1, 2021, from The Express Tribune: https://tribune.com.pk/story/1928241/2-tapi-gaspipeline-makes-headway

Dawn. (2020, November 12). Govt urged to expedite work on power supply from Central Asia. Retrieved June 30, 2021, from Dawn: https://www.dawn.com/news/1589893

Hassan, K. (2020). CPEC: A win-win for China and Pakistan. Human Affairs, 30(2), 212223.

James, S. (2021, May 11). China-Pakistan Economic Corridor-Project Will Approximately Cost of \$ 64 billion. Retrieved June 30, 2021, from The News Engine: https://thenewsengine.com/china-pakistan-economic-corridor-projectwill-approximately-cost-of-64-billion

Javaid, U., \& Naseem, N. (2014). Prospects of Pakistan-Central Asia Economic Relations. Journal of Political Studies, 21(1), 31-40.

Javaid, U., \& Rashid, A. (2016). China Central Asia Relations and Opportunities for Pakistan. South Asian Studies, 31(2), 541-559.

Khan, S., Ali, S., \& Urooge, S. (2019). The Analysis of Regional Bilateral Trade Between Pakistan and Central Asian Republics. Pakistan Journal of Applied Economics, 29(1), 93-106.

Khatoon, N., \& Younes, I. (2019). Pakistan's Interests/Opportunities \& Constraints in the Central Asian States. Journal of the Punjab University Historical Society, 32(2), 45-56.

Khetran, M. S., \& Humayun, M. (2019). The China-Pakistan Economic Corridor Gateway to Central Asia. China Quarterly of International Strategic Studies, 5(3), 455-469.

Latif, A. (2021, June 6). Pakistan, Tajikistan call for a political settlement in Afghanistan before the US pullout. Retrieved June 30, 2021, from Anadolu Agency: 
https://www.aa.com.tr/en/asia-pacific/pakistan-tajikistan-call-for-politicalsettlement-in-afghanistan-before-us-pullout/2261713\#

Mustafa, D. G., Yaseen, D. Z., \& Junaid, A. (2020). Role of Pakistan in Afghan Peace Process. Palarch's Journal of Archaeology of Egypt/ Egyptology, 17(12), 324340.

Ollard, H. (2021, February 25). What's Behind the Planned Uzbekistan-AfghanistanPakistan Railway? Retrieved June 30, 2021, from The Diplomat: https://thediplomat.com/2021/02/whats-behind-the-planned-uzbekistanafghanistan-pakistan-railway/

Sofi, M. D. (2019, January 5). The dynamics of Pakistan-Central Asia engagement. Retrieved June 30, 2021, from Daily Sabah: https://www.dailysabah.com/oped/2019/01/15/the-dynamics-of-pakistan-central-asia-engagement

The Afghanistan Times. (2021, March 1). Gaining Political Maturity. Retrieved July 1, 2021, from The Afghanistan Times: http://www.afghanistantimes.af/editorialgaining-political-maturity/ 